Article

\title{
Use-Values for Inclusion: Mobilizing Resources in Popular Education for Newly Arrived Refugees in Sweden
}

\author{
Nedžad Mešić ${ }^{1, *}$, Magnus Dahlstedt ${ }^{1}$, Andreas Fejes $^{2}$ and Sofia Nyström ${ }^{2}$ \\ ${ }^{1}$ Department of Social and Welfare Studies, Linköping University, 60174 Norrköping, Sweden; \\ E-Mails: nedzad.mesic@liu.se (N.M.),magnus.dahlstedt@liu.se (M.D.) \\ 2 Department of Behavioural Sciences and Learning, Linköping University, 58183 Linköping, Sweden; \\ E-Mails: andreas.fejes@liu.se (A.F.), sofia.nystrom@liu.se (S.N.) \\ * Corresponding author
}

Submitted: 15 January 2019 | Accepted: 10 April 2019 | Published: 27 June 2019

\begin{abstract}
In times of market reforms and international migration, the Swedish welfare model has been seriously challenged. In the context of the arrival of refugees in 2015-2017, the state turned to civil society in facing up to the challenges. In this article, we direct our attention to the Workers' Educational Association's (ABF) state-funded work with refugees, with a specific focus on the activities conducted, the resources making them possible and the use-value of the resources mobilised. The article is based on observations and interviews with study circle leaders, managers and asylum seekers. The analysis illustrates that $A B F$, in line with its historical legacy, the broader workers' movement, the strong notion of popular education as 'free and voluntary', has, with its well-established connections throughout the country, not solely taken on the task defined by the state. In solidarity, ABF has also responded to the needs of the refugees. As highlighted in the analysis, ABF has mobilized a wide range of resources, not least providing refugees with social networks and help in contacting the authorities. With such mobilization, opportunities were provided for the inclusion of refugees in Sweden.
\end{abstract}

\section{Keywords}

asylum seeker; civil society; inclusion; migrants; popular education; refugee; Sweden model

\section{Issue}

This article is part of the issue "The European Refugee Controversy: Civil Solidarity, Cultural Imaginaries and Political Change", edited by Gert Verschraegen (University of Antwerp, Belgium) and Robin Vandevoordt (University of Oxford, UK/University of Antwerp, Belgium).

(C) 2019 by the authors; licensee Cogitatio (Lisbon, Portugal). This article is licensed under a Creative Commons Attribution 4.0 International License (CC BY).

\section{Introduction}

Current migration patterns in Europe, and particularly the historically high number of refugees arriving in Sweden and other member states of the EU, are challenging in terms of inclusion. How can refugees and migrants be supported in order for them to gain access to the labour market and Swedish society more widely? This question comprises a number of policy challenges and institutional innovations not only for the government, regional organizations and municipalities, but also for social partners and in a broader sense civil society. Asylum seekers are facing several problems and shifting conditions with regard to formal assessment of identity and citizenship, living conditions, local community relations, social networks, labour market, welfare and caring and curing institutions. Thus, the asylum process is a complex process of life transition and everyday learning, adapting to new conditions. Educational and occupational background, recognition of prior learning as well as language training are crucial components for the adaptation to the Swedish society and labour market (see e.g., Delmi, 2015).

In order to face these challenges, a wide range of institutions and actors have been mobilised, not least within civil society. Over the last century, there has been 
a close relationship between the state and civil society organisations in Sweden, as part of corporatist arrangements of the Swedish welfare model-a model that, however, is changing. More and more tasks, previously ministered by the state, are now conducted by organisations in civil society. In this article, we focus on one such activity emerging in response to the refugee challenges of 2015-Swedish from day 1. Here, the state invited civil society organisations, among them study associations, to apply for funding in order to provide adult asylum seekers with introduction to Swedish language and society. The invitation was taken up by all ten study associations in Sweden. In this article, we investigate the resources mobilized in such activities, and the ways in which inclusion is facilitated through such mobilizations. By focusing on the use-value of resources mobilised by civil society, the aim of the article is to analyse how public funding in the wake of the recent refugee situation in Sweden becomes transferred into public benefit in the form of inclusion of newly arrived migrants. The article thus examines the implications of collaboration between the state and civil society, and how added value of publicly funded civil society engagements becomes generated vis-à-vis resource conversion in the free and voluntary form of popular education.

\section{Background}

\subsection{A Changing Swedish Welfare Model}

The Swedish welfare model has been described as characterized by its 'de-commodifying' provision of welfare services, based on the pillars of industrial development, full employment, economic growth and income redistribution (Esping-Andersen, 1990; Weiss, 1998). One of the model's main characteristics was symbolised by the institutionalised collaboration between employer and trade union organisations (Edling, 2019). In this model, relations between the state and civil society organisations, referred to as 'people's movements' (folkrörelser), were seen as important for developing a more equal and democratic society. Accordingly, a wide range of interest groups was involved in the decision-making process, thus becoming part of the social democratic welfare project (Rothstein \& Bergström, 1999). The idea with such arrangement was to embed decisions in broad layers of the population, at the same time as high levels of participation in the activities of such organisations would contribute to a democratic fostering of the population (Dahlstedt, 2009a; Edquist, 2009).

The state has for the last century, to varying degrees, funded popular education as a part of the corporatist Swedish model-at the same time as popular education has been 'free and voluntary' (Micheletti, 1995; Premfors, 2000). However, in the 1980s and 1990s, these corporatist arrangements changed, with a wider transformation gradually influenced by neoliberal rationalities (Larsson, Letell, \& Thörn, 2012). Starting in the late 1980s, several of the pillars of the Swedish model were challenged. In all, the centralized welfare state was now seen as an obstacle to the individual's freedom and active responsibility (Boréus, 1994). Eventually, following the early 1990 s economic recession and the election of a centre-right government, by the mid-1990s, the Social democrats had undertaken the development of a 'new Swedish model'. It entailed a radical shift, from equality to freedom of choice, redistribution to activation, collective rights to individual responsibilities as the main ideas guiding the development of welfare policy in Sweden (Dahlstedt, 2015; Edling, 2019).

The established corporatist arrangements gradually became disintegrated, as they were criticized for being too centralized, state-directed and, thus, paternalistic, co-opting the civil society organisations (cf. Rothstein \& Bergström, 1999). However, in the 1990s the idea of collaboration between state and civil society reappeared, in the form of the increasingly widespread notion of partnership. According to this notion, collaborations between state, civil society and private organisations were seen as being necessary in order to deal with societal challenges. To be successful, such partnership arrangements were seen as in need of being decentralized, short-term and based on the transgression of boundaries between public and non-public sectors (cf. Dahlstedt, 2009b).

\subsection{Integration Policy in Change}

In a contemporary academic debate concerning integration policies among EU member states, the state of national integration models has been a contested issue. Here, Joppke (2007) has argued that multicultural integration models have generally converged, in line with an assimilationist development, to such an extent that making distinctions between national model in terms of integration becomes superfluous. Although adhering to the prevalence of such conversion, Jacobs and Rea (2007) contend that dominant integration policy discourses in different member states, by and large, are still rather intact. They argue that it is, nevertheless, both possible and relevant to distinguish path dependencies in terms of national models and policy choices concerning integration.

However, in the wake of the refugee situation in Europe since 2015, major policy changes have recently been made, not least in the case of Sweden. From an international perspective, Swedish integration policy was for a long time widely recognized, not least in research (cf. Borevi, 2014; Schierup, Hansen, \& Castles, 2006), for being an inclusion pioneer and a symbol of the citizenship model described by Castles (1995) as multiculturala model based on the principles of inclusion (making it relatively easy to obtain citizenship) and recognition (guaranteeing minorities certain group rights). However, with contemporary developments, such notions of 'Swedish exceptionalism' (Schierup \& Ålund, 2011) have 
been seriously challenged due to major policy changes, towards a more repressive approach. In political discourse, it has become more or less widely accepted that migration creates societal problems and tensions, that 'integration has failed' and that 'parallel societies' are emerging, not least in the suburbs where most of the migrants live (Sernhede, Thörn, \& Thörn, 2016). Based on such discourse, there has been an increasingly sharp focus on repressive measures with an emphasis on citizens' duties rather than on their rights - primarily aimed at migrants (cf. Dahlstedt \& Neergaard, 2016; Gardell, 2016).

Such discourse has induced suggestions that the borders surrounding the national community should be closed and that specific community 'values' need to be protected from threats located both beyond and within the national community. Such development has not least taken place during and in the aftermath of the 2018 Swedish general election, which became a strong electoral success for the right-wing populist party the Sweden Democrats. It was followed by a rightleft political interlacement and government proposals on restricted migration policies, combined with integration measures extending workfare and sanctions specifically targeting newly-arrived refugees (Social Democrats, 2019). Altogether, these policy changes are similar to those seen during the last decade in, not least, other EU member states (cf. Duyvendak, 2011; Houdt, Suvarierol, \& Schinkel, 2011).

Yet, what has been referred to as the long summer of migration in 2015 (cf. Hess et al., 2017) has induced the need for critical analyses of integration policies executed in different EU states, the role of civil society and migrants' mobilisation, and the emergent social relations and cultural encounters (Youkhana \& Sutter, 2017). In one study, Karakayali (2017) examines emotions in German social movements in relation to newly arrived refugees, illustrating how volunteers' emotional management in the form of refraining from emotional involvement induce a narrow, rather than transnational form of solidarity-thus maintaining established boundaries of belonging, furthering the volunteers' local belonging visà-vis an emotional regime of charity. In another study of the mobilisation of middle-class volunteers in Germany, Fleischmann and Steinhilper (2017) describe the complexities of such mobilisation: on the one hand, there is a constant risk that such mobilisation will reproduce already existing hierarchies and inequalities. On the other hand, there is a potential in this engagement, for the development of new political subjectivities-facilitating contesting public discourse interventions. In the Austrian context, De Jong and Ataç (2017) have drawn attention to the engagement of social movement-oriented NGOs, identifying the creation of spaces where encounters between refugees and engaged activists take place, offering possibilities for the development of new forms of solidarity and belonging. These spaces, in turn, make it possible to break refugees' isolation and provide volunteers with both a sense of responsibility and opportunities for par- ticipation in political struggles for extended citizenship rights of refugees.

\subsection{Study Associations, Swedish from Day 1 and Material}

Turning to Sweden post-2015, and specifically to the mobilisation of popular education, an extensive engagement for the inclusion of newly arrived refugees has been identified, conducted largely outside the formal task set by the government. Such engagement has been aimed at providing refugees with a home in Sweden, and for the refugees to become part of Swedish society (cf. Fejes, 2019; Fejes \& Dahlstedt, 2017; Håkansson \& Nilsson Mohammadi, 2018; Nordvall, Pastuhov, \& Osman, 2018). In this article, focus is specifically directed towards the mobilisation of popular education and particularly study associations, in relation to the inclusion of newly arrived refugees.

There is still a strong notion of popular education as 'free and voluntary', and in this sense, there is a continuity with the long corporatist tradition in the Swedish welfare model. In terms of popular education, the state provides basic funding to folk high schools and study associations, in order for these institutions to provide courses and study circles of their own design, in terms of content as well as pedagogical forms. Furthermore, participation in these activities is voluntary. Thus, popular education is 'free and voluntary', in terms of organisation as well as participation. However, study associations and folk high schools need, at least in relation to the activities conducted based on state funding, to follow the state aims for popular education. These aims are broadly defined in terms of giving 'everyone the possibility, together with others, to increase their knowledge and 'bildung' for personal development and participation in the society' (Swedish Code of Statutes, 2015). Popular education should also, according to the aims of the state, support activities that contribute to the strengthening and development of democracy, increase people's influence on their life situation, create engagement to participate in societal development, and close the educational gaps between individuals and groups in society.

Over time, other means of income for popular education institutions than state funding have become important, not least due to drastic decrease in funding for popular education on the local level (i.e., by county and municipal councils). Such other means of income could be commissioned tasks by the state, municipalities or state agencies. One such commissioned task is the focus of this article, namely Swedish from day 1. In the autumn 2015, the Swedish government, facing the largest migration flows since the Second World War, made funding available for study associations (and to some extent folk high schools) in order to set up study circles for asylum seekers providing an introduction to the Swedish language and society. Between the autumn of 2015 and the end of 2017, more than 120,000 unique 
participants (asylum seekers) had taken part in these activities, which makes up more than half of all asylum seekers arriving in Sweden during this period (Fejes \& Dahlstedt, 2017; Fejes, Dahlstedt, Olson, \& Sandberg, 2018; Swedish Government, 2017).

\section{Empirical Material and Methodological Considerations}

Empirically, the largest study association, the Workers' Educational Association (ABF), was selected for further study. ABF was the study association with the most participants registered in Swedish from day 1, and there was already well-developed collaboration between the study association and the researchers, i.e., access was easy. Three different ABF locations in Sweden where Swedish from day 1 was carried out were chosen for further study: one large city, one medium-sized city and one small town.

In order to gain insight into and background information on what took place in these study circles, before conducting interviews we participated as observers in each location, taking field notes and conducting informal conversations. We also collected documentation concerning the activities (course plans, teaching material, etc.). The observations also made it possible for the participants to get acquainted with us and what we were doing, which thus made the planning and conduct of the interviews easier. At each site, a sample of participants, study circle leaders (SCLs), and managers were chosen for semi-structured interviews. All managers and SCLs working with the activities were interviewed. Among the managers, 3 were female and 6 male. Manager 2 and 3 were employed by $\mathrm{ABF}$ regional headquarters in Large City, while managers 5 and 6 were employed by $A B F$ in Mid-City as well as Small Town (they were co-responsible for both locations). Managers 1, 4, and 7-9 were employed by three migrant organizations with whom $A B F$ cooperated in Large City, which below will be denominated as ABF Large City local offices. Among the SCLs, 4 were female and 4 male. SCL 2-4 and 6-8 worked in Large City, while SCL 1 and 5 worked in the other two locations.

Among the participants, we wanted to select an equal number of persons at each site, as well as securing representation in terms of age, gender, country of origin and educational and occupational background. 21 of the 46 interview persons were female and 25 male. There was an age span between 20 and 60 years, and the interviewees mainly originated from Afghanistan, Syria and Iran. ABF was for all the participants their first encounter with education in Sweden. Some of them had only been in Sweden for as little as three weeks, while others had been in Sweden waiting for a decision on their asylum application for up to three years.

Each interview lasted between 20 and 75 minutes. Interviews with participants were generally shorter as compared to those with managers and SCLs. The project has undergone ethical vetting and been approved by the regional ethical committee in Linköping (Dnr 2017/280-31). Each interviewee was informed about the research, the possibility of their withdrawing at any time, and the fact that the information would be securely stored as well as the identifying markers being deleted/changed in coming publications in order to safeguard their anonymity.

Manager interviews focused on the organisation of Swedish from day 1 and rationales for engagement. Questions asked concerned engagement motives in these activities, their educational and occupational background, activity organisation, their thoughts about their participants and involvement in other tasks than managing the activities. The circle leader interviews centred on motives for engagement, educational and occupational background, their teaching and participants, as well their involvement in tasks other than teaching. As will be illustrated, most of the SCLs themselves had experiences of migration. In participant interviews, we focused their ideas about their current studies and how these related to their past experiences of work and education, as well as to their dreams of the future. Surprisingly, we did not need interpreters. Most interviews were conducted in Swedish, some in English, and one in Bosnian. All interviews were transcribed verbatim and edited for readability.

\section{Analytical Perspective and Analysis}

This article departs from an approach to social movements focusing specifically on resource mobilization as a means of collective action (cf. McCarthy \& Zald, 1973). In line with the broader tradition of popular movements in Sweden, ABF mobilizes a wide range of resources in order to provide popular education to all adults, as a social right. With the aim of combating social inequalities, not least in terms of social class, ABF promotes adult learning based on equal encounters among people with specific experiences, interests and living conditions. In order to further analyse the mobilization of resources in the case of ABFs activities targeting newly arrived refugees, we employ a typology of resources developed by Edwards and McCarthy (2007). According to Edwards and McCarthy (2007, p. 142), 'the availability of diverse kinds of resources to social actors and privileged access to them...enhances the likelihood of effective collective action'.

In the five-fold typology proposed, they distinguish between material, human, social-organizational, cultural and moral resources. Material resources include financial and physical resources such as money, property, equipment, supplies and office space. Human resources consist of access to skills, experience and labour, within or outside the organization. These are commonly embodied in the individuals involved in the organization, in the form of leaders, staff and volunteers. Socialorganizational resources may be divided into three different forms: infrastructures (such as postal services, trans- 
portation, the internet), social networks and organizations, and more specifically access to the resources embedded in these, in terms of contacts, potential coalitions as well as recruiting volunteers. Cultural resources include widely known and accessible ideas, traditions, conceptual tools, and tactical know-how, for instance concerning how to conduct collective action, run a meeting or make decisions. Such resources also include the use and production of cultural artefacts such as literature, music, magazines or websites. Moral resources include legitimacy, solidarity and sympathetic support, most often located outside of the organization, and granted by external sources. As these external sources may also choose to retract such resources, moral resources may be less accessible than, for instance, cultural resources.

Resources may have different attributes. One such attribute is that of 'use-value', i.e., how easily resources are transferred between persons or organisations and thus converted into resources of other kinds-for instance, as in converting money by the purchase of equipment, the hiring of staff or the production of cultural products. Money is generally quite easy to convert into other kinds of resources. This means that organizations with access to large amounts of monetary resources enjoy greater flexibility in terms of the strategies available to them. Other kinds of resources, not least social-organizational and human, are comparably more context-dependent and, thus, difficult to convert into other resources.

Furthermore, there are various mechanisms of access and resource sources, such as self-production and patronage. Resources are not always easily accessible, and so to speak 'ready' to be mobilized, but resources may also be produced within the organisation itself, for instance by the creation of cultural frames and the training of activists. Patronage refers to the existence of a substantial amount of financial support provided by 'patrons' external to the organisation, seeking to influence the way in which money is actually used. Kaldor (2003) problematizes such influences on the part of the state in terms of 'domestication' by which the civil society would substitute state services in exchange for becoming institutionalized, and hence drift away from its activistoriented agenda.

Drawing on the typology of resource mobilization, the analysis is focused on the ways in which resources are mobilized in the activity Swedish from day 1, and how inclusion of newly arrived refugees might be made possible through such mobilizations. Specific attention is drawn to the ways in which the organisation and setup of the activity is described in interviews with people involved in the activity, i.e., managers, SCLs and participants. All interviews conducted were thematically analysed, guided by the analytical approach outlined. Here, the focus was on identifying commonalities and differences across interviews, as well as geographical settings, in terms of how resources are mobilized, and converted and by which means resources are accessed.

\section{Result}

In this section, we introduce our results. These are divided into two parts. In the first part, we discuss the mobilization of resources in the activities arranged by $A B F$ and in the second we discuss the use-value of such mobilizations.

\subsection{Mobilizing Resources}

In our interviews, ABF has, by persons in all interviewee categories, been portrayed as a hub where study circle participants become acquainted with state bodies and their services and other civil society organisations. The head of one local Large City office expounds on the matter:

We have had 25 years of experience with education and we have vast contacts with the Migration Board, Public Employment Service, the National Society for Road Safety...and we have many presentations for our participants regarding road safety, employment and social security services. There are, besides [the circle], many matters regarding society...and they come and explain to our participants. (Manager 4)

Apart from the actors mentioned here, prominent societal actors that the participants, circle leaders and managers refer to include a dental office offering free care, the Swedish Church and local social services informing them about child services and related laws. As we can further see in a participant's excerpt below, the list of organisations involved in the activities of the study circles is quite long:

Last week somebody came from the Swedish Public Employment Service. A couple of months ago a police officer came who spoke about laws and regulations...and recently...information about health care in Sweden. Somebody came and spoke about nature conservation. Folkuniversitetet [an adult educational association] also came and talked about their free of charge courses that one can attend, [and how to] validate earlier education. (Participant 46)

Apart from the study circle, ABF also arranged for and created conditions for other activities that took place in relation to the study circles, such as language cafés, learning how to ride a bike and swim, cook, apply for job and make study visits. The language café is an activity that is highlighted in all contexts. The café was located at ABF's premises, where the participants have the opportunity to drink coffee, meet other participants as well as Swedes and thus practice speaking Swedish. One participant said:

There was a language café here. It helped us a lot. Swedes came here. We drank coffee and tried to talk 
to everyone. We talked like this: 'What's your name? Where are you from?' Everything, you dared to talk. (Participant 4)

In interviews with participants, SCLs, and managers, such an introduction to and interaction with influential societal organisations is described as one of the cornerstones of the programme. In parallel to the extensive mobilisation of socio-organisational resources, our empirical data has also revealed organisational strains in securing material resources such as supplies, staff wages and adequate premises.

Counteracting strategies to such strains include both self-production and resource mobilisation arrangements such as the establishment of affordable course literature lease programmes; and patronage-based arrangements in the form of the use of municipal registers for volunteers; the use of state wage-subsidised employments for circle leaders; and, in the case of one Large City local office, a successful application for a supplemental project grant. Despite such examples of successful forms of external mobilisation of material resources in terms of project grants, this local office has also been cornered in finding makeshift solutions such as alleviating a lack of classroom space by disposing of office-space for the course work. One of the managers at Large City ABF regional headquarters expounds further on the matter of accumulating material resources:

For most of the them [SCLs], it is some type of labour market subsidy programme...but it is still a cost to the association, even if a subsidy is received...and we come in and cover up...with at least one part of the cost of the difference. So, we finance the teachers...and, these associations [Large City local offices] have actually in principle no other assets whatsoever. They have no association subsidy from the municipality as athletic clubs and the like have. (Manager 2)

Another counteractive measure to redeem the everpresent burdens related to material resources that we encounter links in with the ideological and historical foundations of the $A B F$, i.e., its cultural resources. Activities that were directed to asylum seekers were stated to be highly prioritised due to their clear accordance with the ABF's founding mission and educational ambitions for workers' educative development. According to the managers of $A B F$, this has contributed to a further strengthening of the Swedish from day 1 programme through local re-orientation of other available material resources. Two managers at the Large City headquarters expound on this type of self-production of material resources vis-à-vis the internal redistribution of capital:

Our mission is the same today, but it's a different target group than 100 years ago. Therefore, it felt the whole time as a calling to be in on this. It is of huge importance for $A B F$ to take part and do what we can to support these people. It costs a lot of money because it is free of charge to the participants. We are pretty much in accord, all of us working at ABF in Large City, that this is a highly prioritized activity...we also use money for this which we take from our regular state grants [for ordinary circles and cultural arrangements]. (Manager 2)

We must sponsor the weakest in the society. That is our ideology, because we are a people's movement organisation, or workers' organisation...We think that these groups (refugees) are important now...maybe 30-40 years ago, it was the workers at Volvo and others. Now, it is these groups who need our education. And, that means that we take a little from privileged groups who have money...and give to these groups that require it. (Manager 3 )

It has accordingly, in the case of the Large City regional headquarters, been possible to re-dispose resources from the regular and larger state grants so as to further extend the financing of the Large City local offices' Swedish from day 1 groundwork. The headquarters' confidence in the local offices derives from a decades long joint delivery of educational and cultural services to inhabitants with a migrant background, and not least, the local offices' successes in mobilising circles with newly arrived migrants as participants. This socio-organisational resource in the form of access to social networks of potential participants has been accredited central usevalue by the headquarter managers. One of them comments on the local offices' capacity to attract asylum seekers to the numerous circle-courses offered:

There has always been a waiting list...to take courses in Swedish and societal orientation. And, that is not something we advertise in some newspapers or on placards; rather, it spreads between friends and acquaintances, relatives and so. So, we have had a waiting list for the courses even before the arrival of this boom in 2015. (Manager 2)

Both the managers and SCLs attest to the use-value of the long-standing relations both with and between local offices, as a means of facilitating the general groundwork. Specific attention is paid to the local offices' extensive human resources embodied in the individuals involved in the organization, in terms of their ability to communicate with participants in their mother tongue, which in turn makes it possible for the local offices to reach the participants. However, these conditionalities are rather disparate in the different contexts we have studied. In contrast to Large City, we have not found similar mobilisation on the basis of ethnic background in Mid-City and Small Town. Contemplating the potential for mobilisation of not least moral resources vis-à-vis migrant organisations, which may aid in attracting newly arrived participants by generating legitimation, signals the im- 
portance of establishing and nurturing of such organisational collaborations.

\subsection{The Use-Value of Resources Mobilized}

In this section, we will scrutinize the use-value of a variety of resources in the realm of study circles as a social support system for asylum seekers. One central aspect is how $A B F$ vis-à-vis its socio-organizational, material and human resources manifested through the study circle itself generates moral resource use-value in the form of participants' attendance, simply by being a place for encounters. Yet, it is not solely referred to as a place where participants simply hang out. Rather, it is described as a safe place, a place where the participants may escape the uncertainties of their everyday lives and thereby 'break' some of the isolation that they express. This also connects up with use-value related to the way in which the studies are organized and how they are regarded by the participants. The circle-form of education has throughout our observations and interviews distinguished itself from its convention where the classroom is isolated by walls and the learning closely follows the curriculum. Instead, the idea of the classroom has assumed an extended form, where activities, previously expounded on vis-à-vis socio-organisational resources, such as visits by external guests and city tours have been regarded by the participants as widely appreciated educational components. On the basis of such arrangements, along with the possibilities of encountering many new people and finding friends, the circles have been framed by the participants in a rather soft-centred respect. One of the participants expounds:

I can only recommend it to those that sit at home; they do not have to. They can come to ABF. Here you will find friends; you can learn Swedish and you can make more connections. $A B F$ is not a school for me, $A B F$ is a home. I feel at home when I'm here. (Participant 1)

Many of the participants in the study express similar opinions about ABF and the study circle Swedish from day 1 as those in the quote above. The use of the metaphor 'home' indicates that there is more going on in the study circle apart from language learning, which indicates that several other forms of resource have been successfully converted into moral resources in the form of participants' articulated satisfaction.

The findings have also provided evidence that show how attending the ABF study circles denotes a feeling of belonging and inclusion, since the participants are not only learning about the Swedish language and about Sweden, but also about the society and how to get around. One participant emphasises the value of and strong will to be included into the Swedish society:

It is by learning the language that I can get into the society. Here, I get to learn the language, the Swedish language, and by using the language, I can get to understand the Swedes better and then learn more Swedish. (Participant 46)

Another participant further reflects on learning vis-à-vis the circle:

Much of the talk is about Sweden as a place, a country. We learn how to orient ourselves, north, south, how many citizens....and last time we had someone here that talked about how to understand traffic and the rules. (Participant 37)

One manager argues that the circle has four functions:

The first function is that you give them a tool, the language, so you can communicate. This is very important. Then you create a meeting place, since these individuals are alone, with different backgrounds, traumatized by their experiences...they have left a country at war and all of that...the circle becomes a meeting point which has a social and psychological meaning for them, a support. The third is that you gain a network which is important in order to find different ways (ahead). To find an apartment, to find work and maybe find each other, a friend, and you can help each other in the tough situation...the fourth is the knowledge they acquire about the society. When they learn Swedish, they can... integrate into the society and get a job. They then know what ways there are. Where is the public employment office, the social service and where to get help? (Manager 3)

The findings also show that the ABF vis-à-vis the various resources mobilised within the circles themselves jointly offers a social form of support through the relationships that are formed between the SCLs and the participants. The use-value of the material resources provided visà-vis state patronage through Swedish from day 1 in this way extends beyond the formal programme funding goals. Thus, rather than drifting away from its activistoriented agenda (cf. Kaldor, 2003), our study illustrates that state patronage, on the contrary, has provided fuel for the activist orientation of ABF. Both the managers and SCLs describe in detail numerous ways how they conduct voluntary and funding programme-supplementary social work in relation to the participants. These activities constitute the study circle context as a kind of liaison centre where both the managers and the SCLs assist the participants with social support in a broad senseone that is akin to 'bureaucratic support' and described as indispensable in encounters with public and business services such as banks, doctors and migration officials. One manager, for example, states that her door is always open to those in need of help, whatever it might be:

I always have my door open, so everyone can come in if they want help in calling the authorities or interpret- 
ing different papers. There is so much to do. Sometimes I stay until ten in the evening, trying to read their letters and maybe writing a 'close relative application' to the Migration Board. (Manager 1)

The relationship that is formed between the participants and the SCL thus expands way beyond the professional responsibilities as SCLs at $A B F$. One reason for this is the precarious situation the asylum seekers are in, and this kind of support is described in terms of an obligation to fellow human beings in despair.

All the SCLs that were interviewed showed a large social commitment, which also extends out into the local community, where they, for example, may run a local sports team or work extra hours at the library. Through these engagements, the SCLs often establish bonds with the participants outside their professional work at $A B F$, i.e., the SCLs also encounter participants in contexts outside of the circle. One SCL states: 'Well, the majority of the participants are my friends as well. I play football with them; I visit them and they come to me' (SCL 5).

However, the close relationships and the social commitments that the SCLs offer the participants in the form of human resources, also come with certain trials. The findings indicate that the SCLs also take considerable responsibility for the welfare of the participants. Many say that they have been or are struggling with how to handle the situation of always being 'on call'. While underlining the importance of the relational aspects of their work, they also emphasize the costs that come with the forming of relationships with individuals that may be transferred to another location or removed from the country at very short notice. One manager states that: 'How they should handle this is very challenging for the participants and our leaders. For many of them, they are not psychologists or social workers; they cannot take care of these individuals' (Manager 3).

Another manager reasons on the investment made when forming a relationship:

There is a risk; you form a close relationship with individuals whose application [to stay in Sweden] are rejected. Yes, it is tough. People that have been here every day and the next day you ask where they are and they have been deported. Then it is very tough for us. (Manager 6)

Despite such hardships, the accounts by SCLs are indicative of a considerable use-value of human resources visà-vis the SCLs principal pursuit for social engagements that are anchored in their interest in benefitting the asylum seekers' welfare. It is apparent that this commitment derives from a will to work with people, but also a will to give something back. A small group of SCLs were born and raised in Sweden, and have a great interest in working relationally with people. Another group, almost all of the SCLs interviewed, have themselves migrated to Sweden, and have corresponding experiences of under- going the asylum process, learning Swedish and building a future for themselves in Sweden. One SCL states:

I think they saw me as a role model and a leader. I could also see myself in them based on my own experience of being a migrant. I worked; I applied for asylum and I got the chance to stay and this makes it easier to work with the participants. (SCL 5)

Another SCL describes his role: 'You explain and give them some of your own experience about society. It is not only about learning Swedish, an introduction to this language; it is more about the society' (SCL 6).

As the quotes illustrate, the SCLs' lived experiences of migration can be emphasised as human resources whose use-value translates into moral resources as the experiences may allow SCLs to act as guiding role models, i.e., be perceived as persons with whom the participants can identify. Thus, SCLs gain credibility and the opportunity to share their experiences while having an understanding of the participants' situation. However, it is not solely the lived experiences of migration among the SCLs that can be used as a resource, but also their mother tongue, which in some study circles is used as a 'springboard' for learning (in those cases where the SCLs share their mother tongue with the participants). As one of the participants describes it: 'Those SCLs that speak Persian...they can explain it better for me and I understand' (Participant 10).

\section{Discussion}

This article has directed attention to one specific case of civil society mobilisation carried out across Europe in the wake of the long summer of 2015 (cf. Hess et al., 2017), taking place in Sweden and specifically within the realm of popular education. In the wake of the 2015 refugee situation, the Swedish state occasioned mobilisation of the civil society in the cause of language studies and introduction into the Swedish society, incorporating ten major study associations in Sweden (cf. Fejes \& Dahlstedt, 2017; Håkansson \& Nilsson Mohammadi, 2018). Among these, ABF was awarded the largest share of the targeted state funding programme for integration-Swedish from day 1. It is this specific activity that has been the focus of this article. On the receiving end, such popular education directed to adult asylum seekers has been seen by the $A B F$ leadership as directly contingent on the resources allocated by the government. However, apart from underlining the centrality of such patronage-based material resources for the operations of $A B F$, we have in this article identified the mobilisation of a wide range of resources as being crucial for the activities carried out within the organisation-material, human, socioorganisational, cultural as well as moral. In the article, we have analysed how different kinds of resources are mobilized within the Swedish from day 1 activities, as 
well as how various resources are converted from one form into another (cf. Edwards \& McCarthy, 2007).

Our data illustrates how state funding of the 'free and voluntary' format of the study circle, by extension, has contributed to the attainment of use-value in the form of socio-organisational resources within ABF. These resources have included the mobilization of an established broad social network of collaboration partners as well as the establishment of new alliances with an extended set of municipal, state and civil society actors throughout society. The material resources mobilised through the state-funded programme have, furthermore, vis-àvis the accompanying moral resource in the form of a widely established legitimacy of the work carried out by popular education organisations more broadly, aided $A B F$ in mobilising yet additional sets of patronage providing material resources such as labour.

In addition to the patronage-based resource mobilisation, $A B F$ has also engaged in extensive self-production of resources, by relocating some of the general state funding provided for the Swedish from day 1 operations. This manoeuvre entails the ways in which cultural resources, in the form of ABF's historical and ideological legacy of striving for workers' rights in the society by means of providing adult education as a social right to the broad sections of the population, in turn may generate additional material use-value. In the operations carried out by $A B F$, newly arrived refugees thus become perceived as the 'new' working class, or rather the working class of today (cf. Dahlstedt, 2009a; De Jong \& Ataç, 2017; Osman, 2007).

One of the central resources for the ground operations found in our study is the one related to the general and extensive engagements on the part of the participants to attend the courses offered, by which the study circles commonly are denominated as a 'home' (as, for instance, illustrated by Participant 1), a place where the participants are seen as belonging and treated as equal fellow beings, even though they are newly arrived. The use-value of the moral resource that the participants' attendance attests to has in turn been coupled with human resources embodied by the SCLs, their own experiences of migration, language skills and familiarity with Swedish society (cf. Fleischmann \& Steinhilper, 2017; Karakayali, 2017). Additionally, both SCLs and participants refer to the study circles and the activities arranged by ABF as a safe place with the potential of breaking the social isolation related to living in refugee camps across the country, by offering the means to get acquainted with the new society and to learn the Swedish language in the 'free and voluntary' format provided by ABF (cf. De Jong \& Ataç, 2017). Not least, the empirical material underscores the participants' appreciation for the social and bureaucratic support provided in the activities conducted, for instance in terms of SCLs helping out with contacts with banks, doctors and migration officers.

However, on the part of the SCLs, such engagements also come at the cost of persistently being emotionally engaged and on the call, which in turn raises questions concerning the ways in which boundaries between the professional and the private sphere are and should be drawn. Even though there is certainly great potential in the efforts and engagement of the SCLs, in terms of social inclusion of newly arrived refugees, there are obvious risks in such a mobilisation of human resources within the organisation, not least considering the risk of SCLs hitting a wall, as there is not really a limit to the amount of work that would need to be carried out in order to meet the needs of newly arrived refugees (cf. Karakayali, 2017).

Conclusively, in line with its historical legacy, and with its well-established connections throughout society, $\mathrm{ABF}$ not solely took on the task defined vis-à-vis state patronage. On the contrary, in converting the material resources provided by the state into other resources, and by mobilizing its traditional activist orientation (cf. Kaldor, 2003), ABF succeeded in both responding to the urgent needs of the newly arrived refugees and gaining legitimacy for such a response-from participants as well as from the state. So then, what is the point of focusing on popular education in terms of resource mobilisation in relation to newly arrived refugees? Despite the rather major shifts in terms of welfare and integration policy taking place in Sweden recently, with a greater focus on obligations, adaptability and individual responsibility (cf. Gardell, 2016; Schierup \& Ålund, 2011), this kind of analysis has made it possible to illustrate the complexities of such developments and is not as clear cut as first might seem to be the case. Popular education offers one example of the existing opportunities to work towards social inclusion in Sweden, in a range of different ways, not the least by mobilising state resources in combination with other available resources. In order for such an endeavour to be successful, moral resources such as legitimacy and trust are needed, and these need to be carefully managed. Concerning popular education in Sweden, such moral resources in terms of legitimacy and trust seem to be rather intact, despite the changes that have taken place. Thus, a focus on popular education might provide space for further debates on how to promote social inclusion in times of migration.

\section{Conflict of Interests}

The authors declare no conflict of interests.

\section{References}

Boréus, K. (1994). Högervåg [Right wing wave]. Stockholm: Tiden.

Borevi, K. (2014). Multiculturalism and welfare state integration. Identities, 21(6), 708-723.

Castles, S. (1995). How nation-states respond to immigration and ethnic diversity. New Community, 21(3), 293-308.

Dahlstedt, M. (2009a). Democratic governmentality. 
Journal for Critical Education Policy Studies, 7(2), 369-394.

Dahlstedt, M. (2009b). The partnering society. The Open Urban Studies Journal, 2(1), 18-27.

Dahlstedt, M. (2015). Discourses of employment and inclusion in Sweden. In E. Righard, M. Johansson, \& T. Salonen (Eds.), Transformation of Scandinavian cities (pp. 61-80). Lund: Nordic Academic Press.

Dahlstedt, M., \& Neergaard, A. (2016). Crisis of solidarity? Critical Sociology, 45(1), 121-135.

De Jong, S., \& Ataç, I. (2017). Demand and deliver. Social Inclusion, 5(3), 28-37.

Delmi. (2015). Integrationspolitik och arbetsmarknad [Policies of integration and labour market]. Stockholm: Regeringskansliet.

Duyvendak, J. W. (2011). The politics of home. New York, NY: Palgrave Macmillan.

Edling, N. (2019). The language of welfare in Sweden. In N. Edling (Ed.), The changing meanings of the welfare state. New York, NY: Berghahn.

Edquist, S. (2009). En folklig historia [A folk story]. Umeå: Boréa.

Edwards, B., \& McCarthy, J. D. (2007). Resources and social movement mobilization. In D. A. Snow, S. A., Soule, \& H. Kriesi (Eds.), The Blackwell companion to social movements (pp. 116-152). Oxford: Blackwell Publishers.

Esping-Andersen, G. (1990). The three worlds of welfare capitalism. Oxford: Polity Press.

Fejes, A. (2019). Adult education and the fostering of asylum seekers into potential 'full' citizens. International Review of Education, 65(2), 233-250.

Fejes, A., \& Dahlstedt, M. (2017). Popular education, migration and a discourse of inclusion. Studies in the Education of Adults, 49(2), 214-227.

Fejes, A., Dahlstedt, M., Olson, M., \& Sandberg, F. (2018). Adult education and the formation of citizens. London: Routledge.

Fleischmann, L., \& Steinhilper, E. (2017). The myth of apolitical volunteering for refugees. Social Inclusion, 5(3), 17-27.

Gardell, M. (2016). Raskrigaren [The race warrior]. Stockholm: Pocketförlaget.

Håkansson, P., \& Nilsson Mohammadi, R. (2018). Slutrapport: Folkhögskolornas verksamhet för nyanlända [Final report: The undertaking of folk high schools for newly arrived immigrants] (Dnr. UTB 3.7-2017/68). Malmö: Malmö University.

Hess, S., Kasparek, B., Kron, S., Rodatz, M., Schwertl, M., \& Sontowski, S. (2017). Der lange sommer der migration [The long summer of migration]. In S. Hess, B. Kasparek, S. Kron, M. Rodatz, \& M. Schwertl (Eds.), Der lange sommer der migration [The long summer of migration] (pp. 6-24). Hamburg: Assoziation A.

Houdt, F. V., Suvarierol, S., \& Schinkel, W. (2011). Neoliberal communitarian citizenship. International Sociology, 26(3), 408-432.
Jacobs, D., \& Rea, A. (2007). The end of national models? International Journal on Multicultural Societies, 9(2), 264-283.

Joppke, C. (2007). Beyond national models. West European Politics, 30(1), 1-22.

Kaldor, M. (2003). Global civil society. Cambridge: Polity Press.

Karakayali, S. (2017). Feeling the scope of solidarity. Social Inclusion, 5(3), 7-16.

Larsson, B., Letell, M., \& Thörn, H. (Eds.). (2012). Transformations of the Swedish welfare state. Basingstoke: Palgrave Macmillan.

McCarthy, J. D., \& Zald, M. N. (1973). The trend of social movements in America. Morristown, NJ: General Learning.

Micheletti, M. (1995). Civil society and state relations in Sweden. Aldershot: Avebury.

Nordvall, H., Pastuhov, A., \& Osman, A. (2018). Studiecirklar av och för migranter [Study circles by and for migrants]. Stockholm: ABF.

Osman, A. (2007). Invandrarföreningar [Immigrant associations]. In M. Dahlstedt et al. (Eds.), Utbildning, arbete, medborgarskap [Education, labour, citizenship] (pp. 341-361). Umeå: Boréa.

Premfors, R. (2000). Den starka demokratin [The strong democracy]. Stockholm: Atlas.

Rothstein, B., \& Bergström, J. (1999). Korporatismens fall och den svenska modellens kris [The fall of cooperatism and the crisis of the Swedish model]. Stockholm: SNS.

Schierup, C. U., \& Ålund, A. (2011). The end of Swedish exceptionalism? Race \& Class, 53(1), 45-64.

Schierup, C. U., Hansen, P., \& Castles, S. (2006). Migration, citizenship and the European welfare state. Oxford: Oxford University Press.

Sernhede, O., Thörn, C., \& Thörn, H. (2016). The Stockholm uprising in context. In M. Mayer et al. (Eds.), Urban uprisings. Basingstoke: Palgrave Macmillan.

Social Democrats. (2019). Sakpolitisk överenskommelse mellan Socialdemokraterna, Centerpartiet, Liberalerna och Miljöpartiet de gröna [Political agreement between Social Democrats, Center party, Liberals and Swedish Green Party]. Socialdemokraterna. Retrieved from https://www.socialdemokraterna.se/ aktuellt/2019/Utkast

Swedish Code of Statutes. (2015). Svensk författningssamling. Förordning om statsbidrag till folkbildningen (2015:218) [Swedish code of statutes. Regulation on subsidies for popular education]. Stockholm: Swedish government.

Swedish Government. (2017). Government budget 2018 (Prop. 2017/18:1). Stockholm: Swedish Government.

Weiss, L. (1998). The myth of the powerless state. Cambridge: Polity Press.

Youkhana, E., \& Sutter, O. (2017). Perspectives on the European border regime. Social Inclusion, 5(3), 1-6. 


\section{About the Authors}

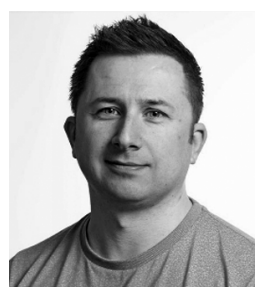

Nedžad Mešić holds a PhD in Ethnicity and Migration and works as a Lecturer in education. His research interest concern migration and inclusion, with particular focus on the engagements of social movements for precarious migrants, newly arrived migrants and young people. (see e.g., Negotiating Solidarity: Collective Actions for Precarious Migrant Workers' Rights in Sweden, Linköping University, 2017).

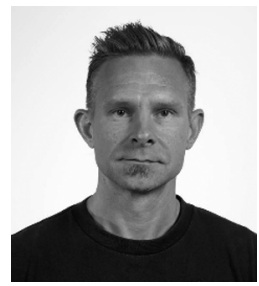

Magnus Dahlstedt is a Professor in Social Work at Linköping University. His primary research interests concern welfare changes, inclusion and exclusion in times of market-orientation and migration. Currently, he is conducting research on civil society organizations and the social inclusion of migrants in Sweden.

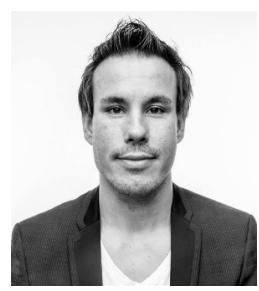

Andeas Fejes is Professor and Chair of Adult Education research at Linköping University, Sweden. His research interests concern adult and popular education with a specific focus on issues pertaining to citizenship and migration. He is currently, together with $\mathrm{M}$. Dahlstedt, directing a research programme on migration, learning and social inclusion, of which this article forms part. Fejes is one of the founding editors of the European Journal for Research on the Education and Learning of Adults.

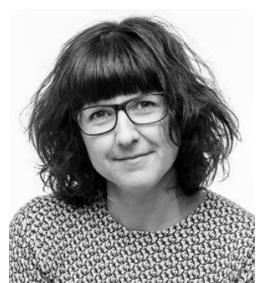

Sofia Nyström is an Associate Professor in Education at the Department of Behavior Sciences and Learning at Linköping University, Sweden. Her research interest focuses on the relation between education and work concerning arrangements for professional and vocational learning as well as identity formation using different theoretical perspectives. She is currently working on a research programme on migration, learning and social inclusion. 